\title{
Numb chin syndrome with metastatic malignancy in hyperpara- thyroidism: Case report
}

\author{
Byung-Yoon Roh ${ }^{1}$, Jong-Mo Ahn ${ }^{2,4}$, Jin-Soo $\mathrm{Kim}^{3,4}$, and Yo-Seob Seo ${ }^{3,4 *}$ \\ ${ }^{1}$ Medical examiner's office, National forensic service, 10, Ipchun-ro, Wonju-si, Gangwon-do 26460, Republic of Korea \\ ${ }^{2}$ Department of Oral Medicine, School of Dentistry, Chosun University, Gwangju 61452, Republic of Korea \\ ${ }^{3}$ Department of Oral and Maxillofacial Radiology, School of Dentistry, Chosun University, Gwangju 61452, Republic of Korea \\ ${ }^{4}$ Oral Biology Research Institute, Chosun University, Gwangju 61452, Republic of Korea
}

(Received Jul 31, 2017; Revised version received Aug 28, 2017; Accepted Aug 28, 2017)

\begin{abstract}
Numb chin syndrome (NCS) is sensory neuropathy characterized by numbness in the chin and lower lip, involving distribution of the mental nerve. Causes of NCS may be of regional origin, a systemic disease, and malignancy. In this study, we report a case of NCS occurring as a first symptom of malignant metastasis in a 57-year-old female patient diagnosed with hyperparathyroidism.
\end{abstract}

KEY WORDS: Hyperparathyroidism, Hypesthesia, Neoplasm Metastasis

\section{서 론}

턱저림 증후군(numb chin syndrome, NCS)은 이부의 신 경병증(mental neuropathy)이라고도 하며, 이신경과 그 가 지의 지배영역에 발생한 감각신경의 신경병증을 지칭한다. 이신경이 분포하는 하순과 이부의 지각감퇴, 감각이상이 발생할 수 있고 드물게는 통증이 나타나기도 한다[1].

$\mathrm{NCS}$ 의 원인은 국소적 원인, 전신적 원인, 악성종양으로 분류될 수 있다. 치성 감염, 국소 마취, 안면부의 외상, 치 아의 외상, 골수염, 악골 및 안면부에 발생한 양성종양 등 의 국소적 원인이 가장 흔하지만 아밀로이드증, 겸상적혈 구빈혈, 당뇨 등과 같은 전신적 원인이나 유방암, 악성림 프종, 폐암 등과 같은 악성종양의 전이에 의해서도 발생할 수 있다. NCS는 악성종양의 첫 번째 증상일 수 있으며 악 성종양의 전이에 의한 $\mathrm{NCS}$ 환자는 치료에 잘 반응하지 않고, 생존 기간이 매우 짧으므로 $\mathrm{NCS}$ 환자에서 전신질환 의 병력 청취 및 구강 내 임상 검사, 진단학적 영상 검사 등을 통해 $\mathrm{NCS}$ 를 유발할 수 있는 요인을 감별하는 것은

*Corresponding author: Yo-Seob Seo

Department of Oral and Maxillofacial Radiology, School of Dentistry, Chosun University, 309 Pilmun-daero, Dong-gu, Gwangju 61452, Republic of Korea

Tel.: +82-62-220-3887, Fax: +82-62-227-0270

E-mail: moresys@chosun.ac.kr
매우 중요하다[2-4].

부갑상선항진증은 혈청 내 부갑상선 호르몬이 과도하게 존재하는 내분비 이상으로 부갑상선 종양이나 과형성으로 인하여 발생하는 경우를 원발성 부갑상선항진증(primary hyperparathyroidism)이라 하고, 저칼슘혈증이 발생하고 이 에 대한 반응으로 부갑상선호르몬의 분비가 증가하는 것 을 속발성 부갑상선항진증(secondary hyperparathyroidism) 이라고 한다[5,6].

부갑상선항진증은 악성종양 발생과 관련이 있다고 알려 져 있으며, Pickard 등[7]은 2425명의 부갑상선항진증 환 자에서 219 례의 악성종양을 관찰하여 부갑상선항진증 환 자의 악성종양 위험이 남성보다 여성에서 더 높다고 하였 고, 원발성 부갑상선항진증 환자에서는 다발골수종과 같 은 조혈성 종양이 증가하지만, 속발성 부갑상선항진증 환 자에서는 모든 악성종양의 발생 위험이 증가한다고 보고 하였다.

저자들은 부갑상선항진증으로 진단한 57 세의 여자 환자 에서 악성종양의 전이의 첫 번째 증상으로 NCS가 발생한 증례를 보고하고자 한다.

\section{증례보고}

57 세 여자환자가 왼쪽 턱 부위에 감각이 이상하다는 것 
을 주소로 OO대학교 치과병원에 내원하였다. 일주일 전부 터 왼쪽 턱 부위에 마취한 듯 한 느낌이 시작되었고, 가끔 저린 느낌도 들었으며 증상이 약간 더 심해지는 것 같다 고 하였다. 혀가 말라서 그런지 2 일 전쯤 자고 일어났을 때 혀 끝의 느낌이 좀 이상했다가 괜찮아졌으며, 전반적인 혀의 느낌이나 맛은 정상이라고 하였다. 뇌 쪽의 이상이 의심되어 병원에 문의하니 치과에 먼저 가보라고 했다고 하였다.

환자는 7 년 전 위암(adenocarcinoma) 수술을, 4 년 전

Table 1. Quantitative sensory testing

\begin{tabular}{|c|c|c|c|c|}
\hline Test site & & $\begin{array}{l}\text { Touch } \\
(\%)\end{array}$ & $\begin{array}{c}\text { Pressure } \\
(\%)\end{array}$ & $\begin{array}{c}\text { Pin Prick } \\
(\%)\end{array}$ \\
\hline \multirow{2}{*}{ Chin } & Right & 100 & 100 & 100 \\
\hline & Left & 50 & 50 & 130 \\
\hline \multirow{2}{*}{ Lip } & Right & 100 & 100 & 100 \\
\hline & Left & 70 & 100 & 80 \\
\hline \multirow{2}{*}{ Labial mucosa } & Right & 100 & 100 & 100 \\
\hline & Left & 80 & 100 & 120 \\
\hline \multirow{2}{*}{ Buccal gingiva } & Right & 100 & 100 & 100 \\
\hline & Left & 100 & 100 & 110 \\
\hline
\end{tabular}

One hundred percent means normal sensation 갑상선암(papillary thyroid carcinoma) 수술을 받았고, 류마 티스 관절염 약을 복용하고 있었다. 2 년 전 암 수술 부위 검진 후, 최근까지 검사를 받지 않았고 근래에 치과 치료 를 받은 적이 없었다. 빈혈이 있고, 귀가 울리며 머리가 아 프지만 이에 대하여는 따로 약을 복용하지 않았다. 딸이 루푸스로 입원하여 스트레스를 많이 받으며 본인도 루푸 스가 발생할지 모른다는 불안감을 가지고 있었고, 수면 시 간은 10 시간 정도이나 불규칙하고 깊이 잠들지 못한다고 하였다.

구강 내 임상 검사에서 하악좌측중절치의 미약한 타진

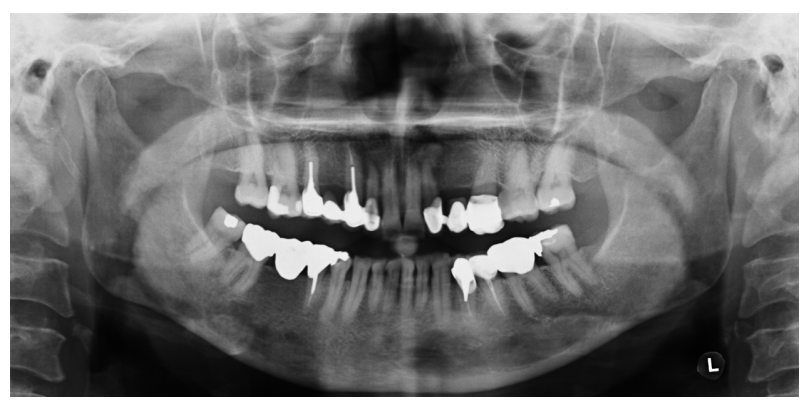

Fig. 1. Panoramic radiograph shows thinning of mandibular cortex and irregular radiodensity within mandible.
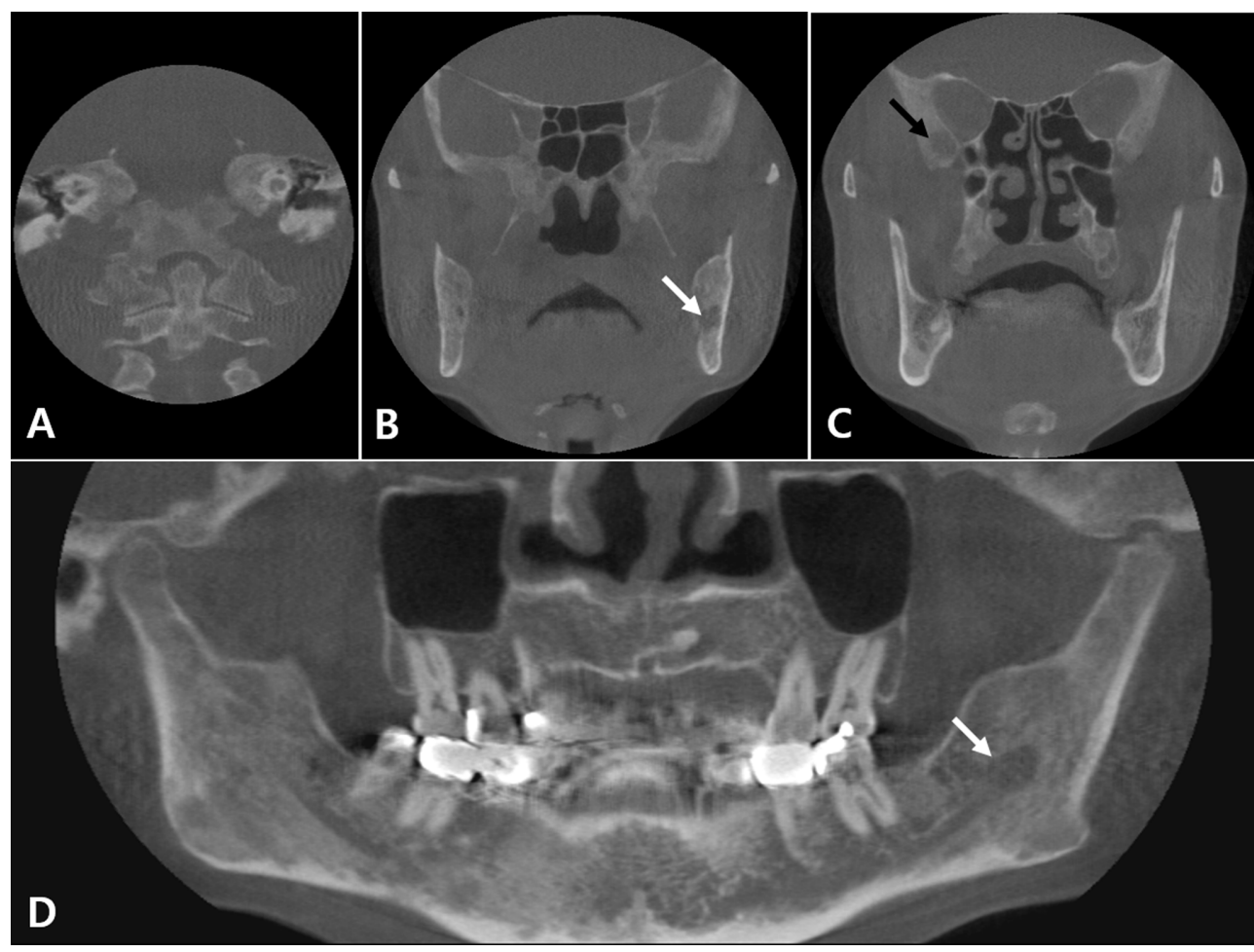

Fig. 2. CBCT reveals the loss of normal cortical boundary and internal ground glass appearance of the bones in head and neck, including cervical vertebra, occipital bone, temporal bone, mandible, and sphenoid bone. Bone fusion of atlas and occipital bone (A) and bone expansion of sphenoid bone with almost loss of cortical boundary (B and C) are observed. Panoramic reconstruction shows ground glass appearance and heterogenic radiodensity in mandible (D). Cortical continuity is relatively remained in maxilla, mandible and zygomatic bone. Note that moderate defined radiolucency with internal faint radiopacity at left mandibular ramus (white arrows in B and D) and right greater wing of sphenoid bone (black arrow in C). 

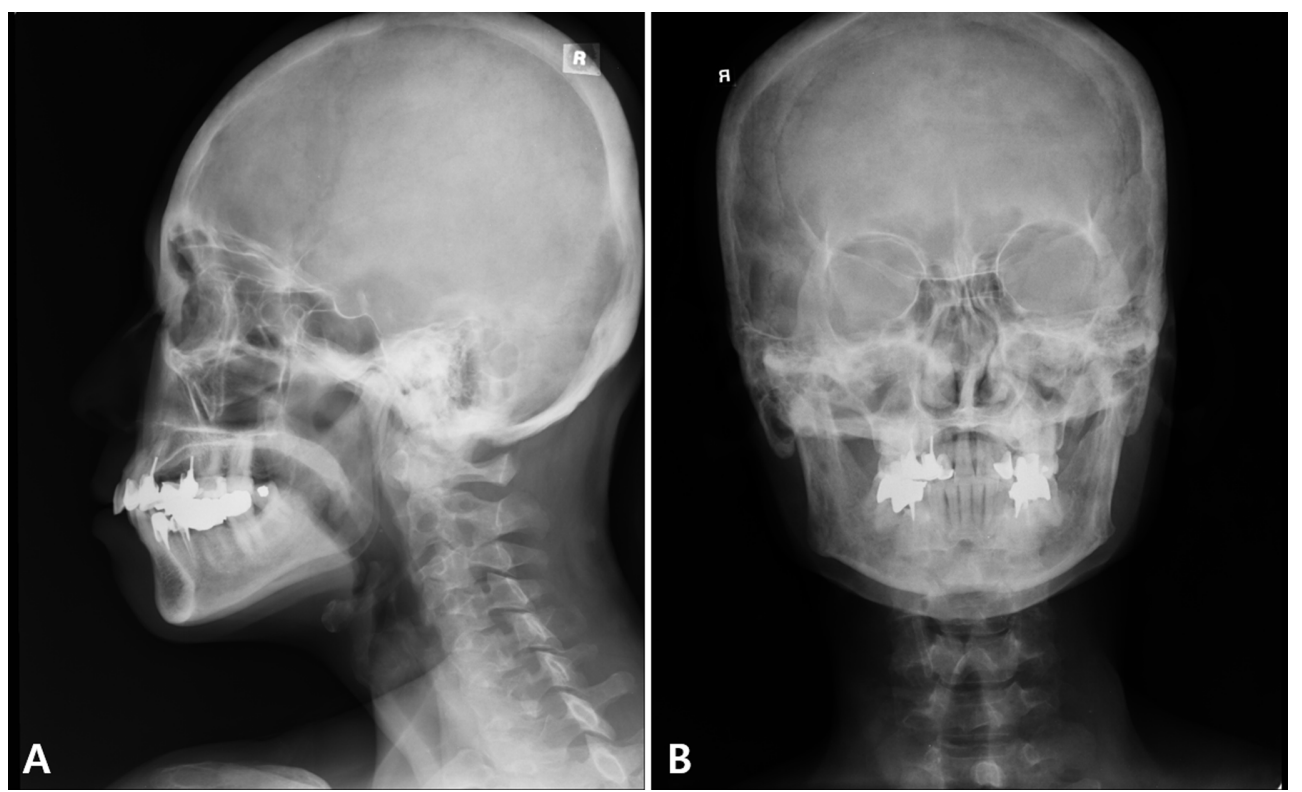

Fig. 3. Lateral skull radiograph (A) and posteroanterior skull radiograph (B) show internal ground glass bone pattern and generalized lack of defined outer cortical boundary of the osseous structure in head and neck. Note the lack of normal cortical bone at the inner and outer tables of the skull.

반응이 있었고 하악좌측제 1 대구치 부위의 경미한 치은 부 종을 제외하고 특별한 이상이 관찰되지 않았다. 정량적 감 각 검사에서 좌측 이부, 아래 입술, 구강 점막 부위의 감 각이 저하되어 있었고 침통각검사에서 부분적으로 과감작 되어 나타났다. 정중부는 비교적 명확하게 구분하였으나 후방 부위는 명확하게 표시되지 않았다(Table 1).

파노라마방사선영상에서 하악각 하연의 피질골이 얇아 져 있었고, 하악지 및 하악체가 전반적으로 균일하지 않은 방사선불투과상을 보였으며 하악관의 경계가 불명확하였 다(Fig. 1).

하악관 주위의 병소 여부를 확인하기 위해서 콘빔전산 화단층장치(콘빔CT, cone beam computed tomography; $\mathrm{CBCT}$ ) 검사를 시행하였다. $\mathrm{CBCT}$ 영상에서 경추, 후두골, 접형골, 측두골, 설골 등 대부분의 골에서 피질골이 소실 되고 내부가 간유리모양의 골로 채워져 있었다. 접형골은 피질골 대부분을 소실하고 약간 팽융되어 두드러져 보였 고 상악골, 하악골과 관골은 다른 골에 비해 피질골이 비 교적 건전하였다. 상악골은 과립상의 골양상을 보였고, 하 악골은 하악지와 우측 하악체 부위에 간유리모양의 골양 상을 보였다. 좌측 하악지 부위와 우측 안와 외하측의 접 형골에 간유리모양의 골 내에서 경계가 비교적 명확하고 내부에 희미한 방사선불투과상이 혼재되어 있는 방사선투 과상이 관찰되었고, 하악 좌측 병소는 좌측 하악관과 인접 해 있었다(Fig. 2). 두개골의 변화를 관찰하기 위해 추가로 두부방사선촬영을 하였고, 측방두부방사선영상과 후전방 두부방사선영상에서 두개골 내판과 외판의 피질골 소실과,
Table 2. Results of blood test

\begin{tabular}{lcccc}
\hline & & Result & $\begin{array}{c}\text { Normal } \\
\text { range }\end{array}$ & Unit \\
\hline HGB (hemoglobin) & low & 7.8 & $12.0 \sim 16.0$ & $\mathrm{~g} / \mathrm{dL}$ \\
HCT (hematocrit) & low & 25.8 & $37 \sim 47$ & $\%$ \\
RBC (red blood cell) & low & 2.56 & $4.20 \sim 5.40$ & $10^{6} / \mu \mathrm{l}$ \\
WBC (white blood cell) & low & 3.28 & $4.0 \sim 8.0$ & $10^{3} / \mu \mathrm{l}$ \\
Rheumatoid factor & high & 455.00 & $0.0 \sim 15$ & $\mathrm{IU} / \mathrm{mL}$ \\
Intact PTH & high & 132 & $15 \sim 68.3$ & $\mathrm{pg} / \mathrm{mL}$ \\
Alk-phosphatase & high & 929 & $35 \sim 123$ & $\mathrm{U} / \mathrm{L}$ \\
Albumin & & 3.78 & $3.5 \sim 5.2$ & $\mathrm{~g} / \mathrm{dL}$ \\
Creatinine & & 0.68 & $0.5 \sim 1.3$ & $\mathrm{mg} / \mathrm{dL}$ \\
Total Ca & low & 7.94 & $8.4 \sim 10.2$ & $\mathrm{mg} / \mathrm{dL}$ \\
Ionized Ca & & 4.14 & $4.0 \sim 4.8$ & $\mathrm{mg} / \mathrm{dL}$ \\
Inorg. Phosphorus (P) & & 3.39 & $2.5 \sim 4.5$ & $\mathrm{mg} / \mathrm{dL}$ \\
\hline
\end{tabular}

판사이공간에 간유리모양의 골 변화가 관찰되었다(Fig. 3). 영상검사에서 부갑상선항진증이 의심되어 환자에게 추가 로 문진을 실시하였고, 과거 신장 질환 병력을 확인하였다.

환자의 혈액검사상 hemoglobin, hematocrit, red blood cell, white blood cell의 수치가 정상보다 낮았고 Rheumatoid factor는 정상보다 높은 수치를 보였다. Parathyroid hormone 이 $132 \mathrm{pg} / \mathrm{mL}$ (정상: $15 \sim 68.3 \mathrm{pg} / \mathrm{mL}$ ), alkaline phosphatase 가 $929 \mathrm{U} / \mathrm{L}$ (정상: 35 123 U/L)로 정상보다 높았고, total calcium은 $7.94 \mathrm{mg} / \mathrm{dL}$ (정상: $8.4 \sim 10.2 \mathrm{mg} / \mathrm{dL}$ )로 정상보다 낮았다(Table 2).

기존 암의 재발을 확인하기 위해 시행한 양전자방출컴퓨터 


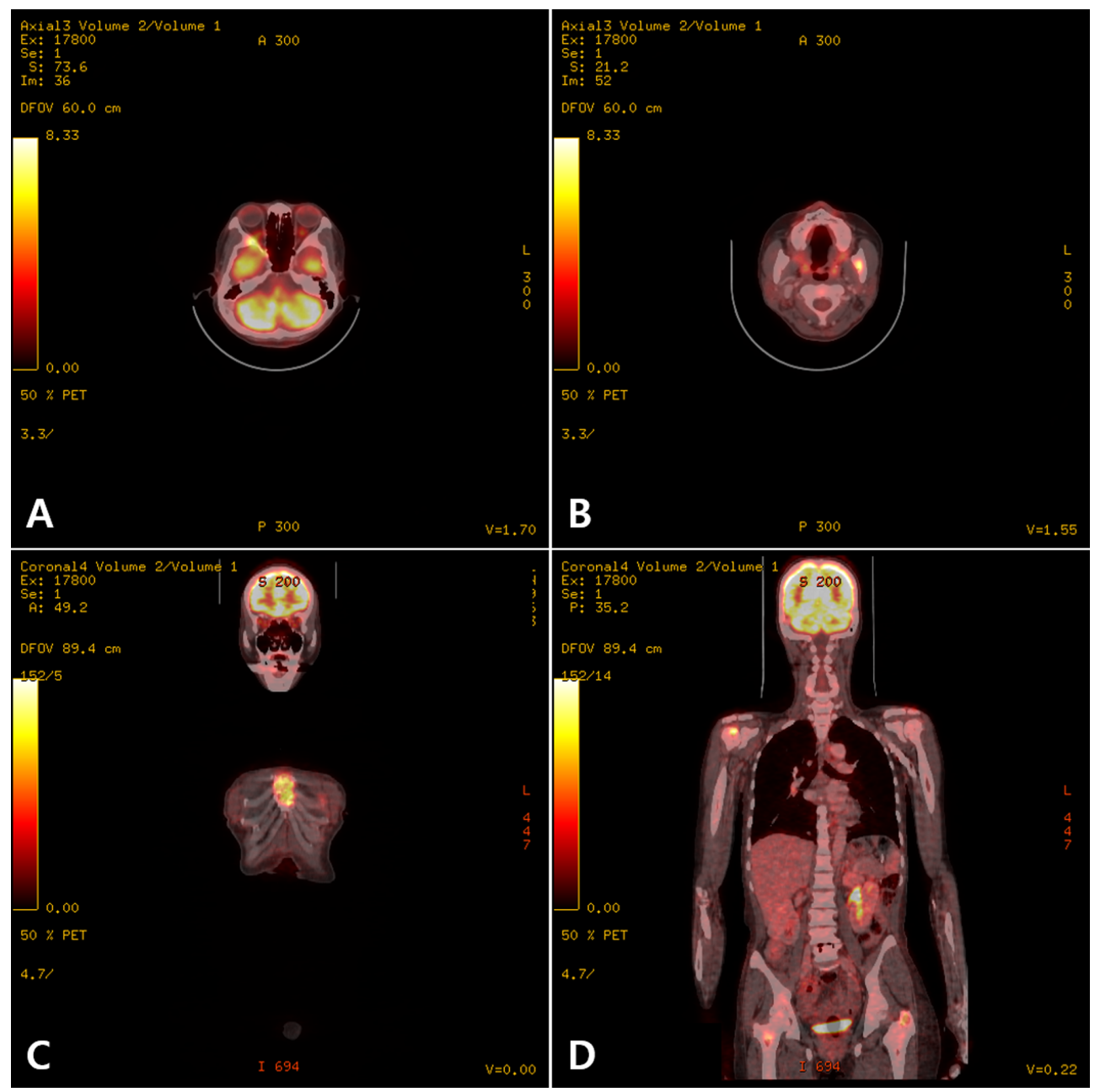

Fig. 4. Positron emission tomography-computed tomography (PET-CT) reveals hypermetabolism in multiple osteolytic lesions in right sphenoid bone (A), left mandible (B), sternum (C), and both femurs and humeri (D).

단층촬영(positron emission tomography-computed tomography, PET-CT)에서 fluorodeoxyglucose (FDG)의 섭취가 증가된 과대사 종괴들이 좌측 하악지, 우측 안와 외측의 접형골, 흥골, 양측 상완골과 대퇴골에서 관찰되었다(Fig. 4). 흥골 부위 병소의 조직검사 결과 전이성 선암종(metastatic adenocarcinoma)으로 진단되었고 이전의 위암(adenocarcinoma) 과 갑상선암(papillary thyroid carcinoma)의 과거력을 고려 하였을 때 위암 기원의 골 내 전이로 생각되었다.

항암치료가 시행되었으나 NCS 발생으로부터 3개월 후 사망하였다.

\section{고 찰}

속발성 부갑상선항진증의 주요 원인은 신부전증으로 알 려져 있다[8]. 속발성 부갑상선항진증이 장기간 지속되었 을 때 부갑상선호르몬이 자율적으로 과도하게 분비되는
이상 상태가 될 수 있는데 이를 삼차성 부갑상선항진증 (tertiary hyperparathyroidism)이라고 한다[9]. 본 증례에서 부갑상선호르몬, alkaline phosphatase가 정상보다 높았고, 혈중의 ionized calcium은 $4.14 \mathrm{mg} / \mathrm{dL}$ 로 정상 범주에 속했 으나, total calcium은 $7.94 \mathrm{mg} / \mathrm{dL}$ 로 정상보다 낮았다. 속 발성 부갑상선항진증에서 삼차성 부갑상선항진증으로의 이행이 의심된다(Table 2).

부갑상선호르몬은 혈청내 칼슘 농도를 높이는 역할을 하는 호르몬으로 파골세포를 활성화하여 골을 흡수시키고, 신장에서 칼슘의 재흡수를 촉진시키며, 신장에서 비타민D 의 활성화를 촉진시킨다. 부갑상선항진증 환자는 골 흡수 가 촉진되고 골 개조가 증가하므로 진단 영상에서 전반적인 골의 탈회, 치조백선의 소실, 피질골의 비박과 소실, 과립상 또는 간유리모양, 낭성섬유골염(osteitis fibrosa cystica), 갈색 종양(brown tumor) 등의 골 변화가 관찰될 수 있다 $[1,10]$.

본 증례에서 파노라마방사선영상과 치근단방사선영상에 서는 특이한 진단 정보를 얻지 못하였다. $\mathrm{CBCT}$ 영상과 
두부방사선영상에서 경추, 접형골, 두개골 등 악골 이외의 골에서 피질골 소실과 간유리모양의 골양상을 관찰하여 부갑상선항진증을 의심하였고 추가로 문진하여 과거 신장 질환 병력을 확인하였다(Fig. 2 and 3). 또한 제1경추와 후 두골의 융합과 같이 환자의 관절염 병력과 연관된 병적 상 태도 확인할 수 있었다(Fig. 2A). 치과에서 $\mathrm{CBCT}$ 등의 진 단 영상 활용 시 악골 이외의 골도 면밀히 관찰하면 환자의 전신 질환에 대한 정보를 얻을 수 있을 것으로 생각된다.

부갑상선항진증에서 나타날 수 있는 갈색종양은 PET$\mathrm{CT}$ 영상에서 과대사 종괴로 나타나 악성종양으로 오인될 수 있다. 전이성 암종과는 달리 갈색종양은 부갑상선호르 몬이 정상화되면 퇴행할 수 있기 때문에 두 병소를 구분 하는 것이 필요하고 이를 위해 조직검사를 시행하여야 한 다[11,12]. 본 증례에서는 하악지, 접형골, 흥골, 양측 상완 골과 대퇴골에 방사선투과성의 병소가 있었고, PET-CT 영 상에서 과대사 양상을 보였는데, 이 중 흥골 부위에서만 조직검사가 시행되었다. 하악지 부위의 병소는 조직검사 가 시행되지 않았으나 갈색종양의 활성형태라고 보기 어 려웠고, $\mathrm{NCS}$ 의 발생과 연관지었을 때 갈색종양 보다는 전 이성 암종일 가능성이 높을 것으로 사료된다.

$\mathrm{NCS}$ 와 연관된 전신적 요인으로는 다발성 경화증, $\mathrm{HIV}$, 당뇨, 매독, 겸상 적혈구 빈혈증, 혈관염, 아밀로이드증 등 이 있으며 쇼그렌증후군, 류마토이드 관절염, 루프스, 전신 성경화증과 같은 결합조직 질환도 신경병증을 일으킬 수 있다고 보고되었다[5-7,13]. 부갑상선항진증도 NCS를 유 발할 수 있지만 근래에는 통상적인 혈액검사에서 조기에 발견되어 처치를 받게 되므로 임상증상을 나타내는 경우 는 거의 없다[2,9,14]. 본 증례에서는 류마토이드 관절염과 부갑상선항진증이 동반되었으나 $\mathrm{NCS}$ 의 직접적인 원인으 로 보기는 어려웠다.

부갑상선항진증과 같은 내분비 장애는 multiple endocrine neoplasia type 1, type 2a, hyperparathyroidism-jaw tumor syndrome 등의 유전적 질환에 의해서도 발생할 수 있고 종양과 연관될 수 도 있다[2]. 본 증례의 환자는 여성이었 고, 류마티스 관절염, 위암, 갑상선암, 부갑상선항진증이 발생하였고, 딸이 전신에 영향을 끼치는 자가면역 질환인 루프스를 않고 있었던 점을 고려할 때 유전적 소인의 가 능성도 배제할 수 없다.

국소적 원인을 제외하면 NCS의 가장 흔한 원인은 악성 종양이다[5]. Gil 등[15]은 16개의 연구에 포함된 NCS 136 례를 분석하여 NCS와 연관된 악성종양은 유방암, 림프종, 전립선암, 백혈병 순으로 빈도가 높고, $\mathrm{NCS}$ 가 악성종양의 $27.7 \%$ 에서, 재발성 병소의 $37.7 \%$ 에서 첫 번째 증상으로 나타났다고 보고하였다. Lossos 등[16]은 42명의 NCS 환 자에서 $89 \%$ 가 전이에 의해 NCS가 발생하였으며, 그 중 $50 \%$ 는 하악골에, $14 \%$ 는 두개저에, $22 \%$ 는 연수막에 발생
하였다고 하였다. 한편, Sanchis 등[17]은 NCS를 일으키는 구강내 원발성 악성종양 11 례중 편평세포암종이 10 례로 가장 높은 빈도를 보였다고 보고하였다. 본 증례는 위암이 재발하였고, 골 내 전이가 일어났으며 그 첫 번째 증상으 로 NCS가 발생한 것으로 보인다.

본 증례에서와 같이 $\mathrm{NCS}$ 환자는 일차적으로 치과로 의 뢰될 수 있으므로 치과의사는 치성 요인을 감별할 수 있 어야 하고, 전신질환을 파악하기 위해 노력하며, 악성 병 소 전이의 가능성을 고려할 수 있어야 한다.

\section{감사의 글}

이 논문은 2014학년도 조선대학교 학술연구비의 지원을 받아 연구되었음.

\section{Conflict of Interest}

The authors declare that they have no competing interests.

\section{ORCID}
Byung-Yoon Roh
$0000-0003-1703-3610$
Jong-Mo Ahn
0000-0002-3615-3688
Jin-Soo Kim
0000-0002-1847-3741
Yo-Seob Seo
0000-0003-1804-5648

\section{References}

1. Zaheer F, Hussain K, Rao J. Unusual presentation of 'numb chin syndrome' as the manifestation of metastatic adenocarcinoma of the lung. Int J Surg Case Rep 2013; 4:1097-1099. doi: 10.1016/j.ijscr.2013.08.024.

2. Jung JK, Hur YK, Choi JK. A Case Report of Numb Chin Syndrome with Facial Pain Caused by Diffuse Large B-Cell Lymphoma. J Oral Med Pain 2011;36:253259.

3. Marinella MA. Numb chin syndrome: a subtle clue to possible serious illness. Hospital physician 2000;36:5460.

4. Oh D, Woo K, Kim ST, Ahn HJ, Choi JH, Kwon JS. Numb Chin Syndrome as the First Symptom of Diffuse Large B-cell Lymphoma. J Oral Med Pain 2016;41:200204. doi: 10.14476/jomp.2016.41.4.200.

5 . Khan AA. Medical management of primary hyperpara- 
thyroidism. J Clin Densitom 2013;16:60-63. doi: 10.1016/ j.jocd.2012.11.010.

6. Neville BW, Damm DD, Chi AC, Allen CM. Oral and maxillofacial pathology. 4th ed. St. Louis: Elsevier Health Sciences; 2015.

7. Pickard AL, Gridley G, Mellemkjae L, Johansen C, Kofoed-Enevoldsen A, Cantor KP, Brinton LA. Hyperparathyroidism and subsequent cancer risk in Denmark. Cancer 2002;95:1611-1617. doi: 10.1002/cncr.10846.

8. Cunningham J, Locatelli F, Rodriguez M. Secondary hyperparathyroidism: pathogenesis, disease progression, and therapeutic options. Clin J Am Soc Nephrol 2011; 6:913-921. doi: 10.2215/CJN.06040710.

9. Selvi F, Cakarer S, Tanakol R, Guler S, Keskin C. Brown tumour of the maxilla and mandible: a rare complication of tertiary hyperparathyroidism. Dentomaxillofac Radiol 2009;38:53-58. doi: 10.1259/dmfr/81694583.

10. White SC, Pharoah MJ. Oral Radiology: Principles and Interpretation 7th ed. St. Louis: Elsevier Health Sciences; 2014.

11. Andersen KF, Albrecht-Beste E. Brown tumors due to primary hyperparathyroidism in a patient with parathyroid carcinoma mimicking skeletal metastases on $18 \mathrm{~F}$ FDG PET/CT. Diagnostics 2015;5:290-293. doi: 10.3390/ diagnostics5030290.

12. Lee JH, Chung SM, Kim HS. Osteitis fibrosa cystica mistaken for malignant disease. Clin Exp Otorhinolaryngol 2013;6:110-113. doi: 10.3342/ceo.2013.6.2.110.

13. Dumas M, Pérusse R. Trigeminal sensory neuropathyA study of 35 cases. Oral Surg Oral Med Oral Pathol Oral Radiol Endod 1999;87:577-582. doi: 10.1016/S10792104(99)70137-X.

14. Krishnan U, Moule AJ. Mental nerve paraesthesia: A review of causes and two endodontically related cases. Saudi Endodontic Journal 2015;5:138. doi:10.4103/1658-5984. 155454.

15. Gil SG, Diago MP, Diago MP. Malignant mental nerve neuropathy: systematic review. Med Oral Patol Oral Cir Bucal 2008;13:E616-E621.

16. Lossos A, Siegal T. Numb chin syndrome in cancer patients Etiology, response to treatment, and prognostic significance. Neurology 1992;42:1181-1184.

17. Sanchis JM, Bagán JV, Murillo J, Díaz JM, Poveda R, Jiménez Y. Mental neuropathy as a manifestation associated with malignant processes: its significance in relation to patient survival. J Oral Maxillofac Surg 2008;66:995998. doi: 10.1016/j.joms.2007.12.046. 